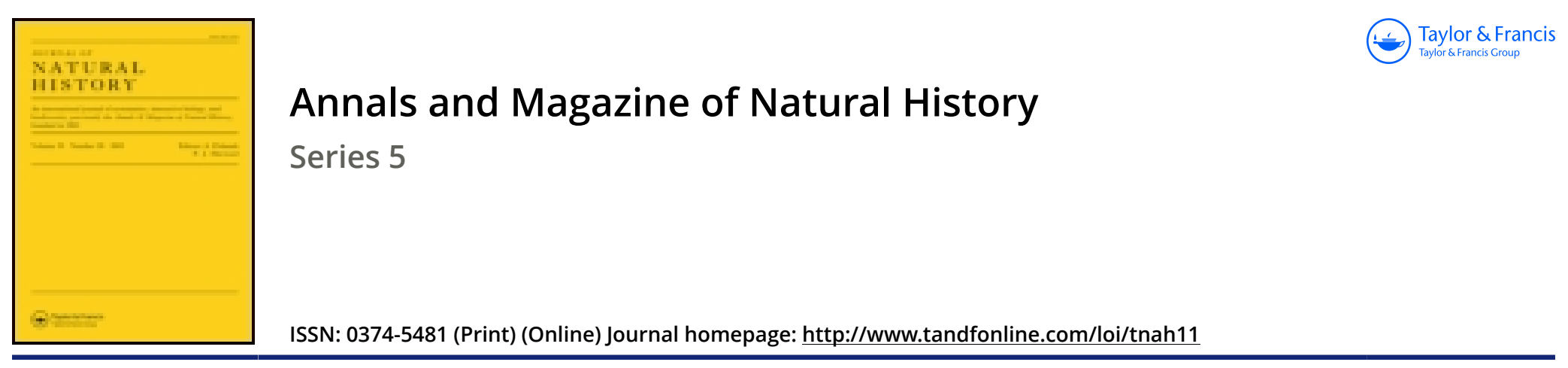

\title{
XLVIII.-On the origin of the fauna and flora of New Zealand
}

\section{Captain F.W. Hutton}

To cite this article: Captain F.W. Hutton (1884) XLVIII.-On the origin of the fauna and flora of New Zealand, Annals and Magazine of Natural History, 13:78, 425-448, DOI: 10.1080/00222938409459272

To link to this article: http://dx.doi.org/10.1080/00222938409459272

$$
\text { 册 Published online: } 07 \text { Oct } 2009 .
$$

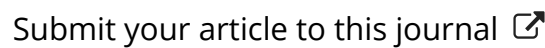

Џ Article views: 4

Q View related articles 5 


\title{
THE ANNAIS
}

\section{AND \\ MAGAZINE OF NATURAL HISTORY.}

\author{
[FIFTH SERIES.]
}

No. 78. JUNE 1884.

\section{XLVIII.-On the Origin of the Fauna and Flora of New} Zealand. By Captain F. W. Hutron *.

\section{The Australian ann South-American Elements.}

Eleven years have elapsed since I read a paper to the Wellington Philosophical Society on the "Geographical Relations of the New-Zealand Fauna " †. During that time the data on which the discussion of this question rests have very much increased, and the literature of the subject has been enriched by the valuable works of Mr. A. R. Wallace on the distribution of animals, works which embody the results of much patient research and acute reasoning. Under these circumstances $I$ wish, in this address, to return to my theme once more. I wish to explain how far I now think my own ideas of $\mathbf{1 8 7 2}$ to be erroneous; how far I am able to agree with Mr. Wallace in his view of the origin of our fauna and flora, published in 1880 in 'Island Life;' and how far,

* Presidential Address to the Philosophical Institute of Canterbury, 1st November, 1883. Reprinted from a separate impression from the 'New Zealand Journal of Science' for January 1884. Communicated by the Author.

$\dagger$ Trans. N. Z. Inst. vol. v. (1872), p. 227 ; and Ann. \& Mag. Nat. Hist. ser. 4, vol. xiii. p. 25.

Ann. \&ag. N. Hist. Ser. 5. Vol. xiii. 
as it appears to me, Mr. Wallace's theory fails to explain the whole of the facts. I also wish to suggest the alterations and additions that seem to be necessary in order to get a good working hypothesis. It will be advisable, however, not to limit ourselves to New Zealand, but to take first a wider view of the subject; for the faunas and floras of Australia and Polynesia are so intimately connected with those of New Zealand, that the origin of the latter cannot well be considered until a general knowledge of the biological and geological history of the Pacific area has been obtained.

Fossil plants have been found in many places in New Zealand, often abundantly and in good preservation, and they belong to several different geological periods. These plants have not yet been described, but they have been examined by Dr. Hector, who has published an abstract of the results of his examination in the 'Proceedings of the New-Zealand Institute,' vol. xi. (1878), p. 536, and in the 'Handbook of New Zealand' (1880). The earliest traces of plants are very obscure, but the Triassic rocks contain ferns (Glossopteris), horse-tails (Schizoneura), cycads (Zamites), and wood of a kauri (Dammara). The oldest known extensive flora is of Jurassic age; it consists chiefly of ferns and cycads, which are closely allied to those which inhabited India at the same period, as exemplified by the fossils of the Rajmahal hills. In the Cretaceous rocks numerous dicotyledonous plants occur, forty different species having been distinguished. These, as well as some conifers, belong to species closely allied to those at present living in the country, although some, such as Araucaria, have become extinct in New Zealand. In the lower beds of the system these plants are associated with ferns that are also found in the Jurassic strata. The flora of the Tertiary era "is badly preserved, and the collections are scanty; but, as far as yet studied, it bears a very close affinity to the recent flora of the country." It thus appears that the main features of the present New-Zealand flora are very old, dating from the Cretaceous period, with a mixture of still older forms among the ferns and conifers.

Let us now turn to Australia. No fossil plants, so far as I know, have as yet been found in Western Australia, but in Eastern Australia they occur in several places. The Palæozoic rocks of Victoria, New South Wales, and Queensland contain Calamites, Lepidodendron, and ferns, in some cases identical with plants of the same era in Europe and America. In the Triassic and Jurassic beds cycads and conifers are found, together with the same ferns which occur in New Zealand and in India in equivalent systems. No plants are 
known of Cretaceous age, but in the Eocene vegetable remaing have been found in New South Wales which, according to Baron von Müller and Baron von Ettingshausen, are all extinct forms but little allied to the present Australian flora; for with Pittosporum, Knightia, and four kinds of Eucalyptus there occur birches, alders, oaks, and beeches; while in Victoria extinct tropical trees are found which resemble those of Asia. The fossil plants mentioned by Mr. Darwin at Geilston Bay, near Hobart, in a freshwater limestone of probably Miocene age, are also very different from those now living in Tasmania. They belong, as Mr. Darwin says, to a lost vegetation*. They represent willows, birches, alders, oaks, and beeches, along with Coprosma, Araucaria, and others. They are more characteristic of Australia than are the Eocene plants; but still both are much nearer to the Tertiary floras of Europe, Asia, and North America than to the recent Australian flora. In beds of newer Pliocene age plant-remains have been found both in New South Wales and in Victoria, and these, according to Baron von Müller, are allied to the present flora of Eastern Australia. What a contrast to New Zealand is here! The present flora of Eastern Australia does not date beyond the Pliocene period, previous to which the country was covered by a lost vegetation allied to the Tertiary floras of Europe and Asia; while in New Zealand, as we have just seen, the present flora dates from the Cretaceous period.

Mr. Wallace has given a very simple explanation of these curious facts. The Australian flora, he says, consists of two large divisions :- (1) the characteristic Australian flora, which is chiefly temperate and hardly represented in New Zealand; and (2) a tropical flora, which is less in number than the first, is closely allied to the floras of India and Malaya, and has many representatives in New Zealand and in South America. Western Australia has no European, Antarctic, or SouthAmerican types, but it is far richer than Eastern Australia in true Australian forms, many of which are only found there. He also points out that a submarine ridge, nowhere more than 1000 fathoms below the present sea surface, runs from New Zealand to Northern Queensland, and that the distribution of the Cretaceous rocks in Australia proves that at that period the sea flowed over the centre portion of the continent, dividing the east from the west. From these facts Mr. Wallace infers (1) that the submarine ridge between New Zealand and North-eastern Australia was elevated above the ocean at the same time that Central Australia was submerged; and

$$
\text { * 'Volcanic Islands,' p. } 140 .
$$


(2) that South-western Australia is the remnant of an extensive isolated continent which received the ancestral forms of its fauna and flora at a very early, probably Jurassic date, by a temporary union with the Asiatic continent over what is now the Java sea; and it was on this continent that the characteristic Australian flora and mammalian fauna were developed: He supposes that during the Cretaceous period Eastern Australia, separated from Western Australia by a wide arm of the sea, supported a flora that was principally tropical and of Polynesian type, derived from the north through New Guinea; but, in addition, there were fragments of the typical Australian vegetation which had reached it as stragglers from Western Australia, and also a few south-temperate forms from antarctic lands, which had arrived from 'lasmania. New Zealand, which at this time is supposed to have been joined to North-eastern Australia, was open to the immigration of the Polynesian flora and of such Australian types as had reached the tropical portions of Eastern Australia. At the close of the Cretaceous period the northern prolongation of land between New Zealand and Queensland sank; New Zealand was separated from Australia, and has ever since remained isolated with its flora. Eastern Australia remained separated from the west until late in the Tertiary era, when Central Australia was elevated. The flora of Western Australia then invaded the east, and exterminated to a large extent the older tropical vegetation and completely changed the character of the flora.

Such is Mr. Wallace's hypothesis, which, except in some details, is so far satisfactory, the only obvious objections being (1) that the origin of the Australian flora is attributed to a period when no Dicotyledons are known to have existed, and (2) that the majority of the characteristic Australian mammals belong to Eastern and not to Western Australia. These are difficulties, however, which further knowledge may dispel ; but the hypothesis cannot be considered as a complete solution of the problem, because one large class of facts is not satisfactorily explained. I allude to the South-American types found in Eastern Australia and New Zealand, many of which belong to tropical and subtropical genera. Mr. Wallace's explanation of the presence of these forms is that a migration took place through New Zealand, South Victoria Land, South Shetland Islands, and Tierra del Fuego over a

* This had been indicated by the Rev. J. Tenison-Woods in the Proc. Roy. Soc. Tasmania, 1875, p. 20, and previously by Prof. Jukes in his Physical Structure of Australia,' quoted by Hooker, 'Flora Tasmaniz;' Intr. p. ci. 
greater extension of southern lands during a warm Miocene period. Now Dr. P. Martin Duncan is certainly of opinion that the sea in this portion of the southern hemisphere was much warmer in the Miocene period than at present, and he has suggested that this was due to an extension of the Antarctic Continent up to $50^{\circ} \mathrm{S} . *$; but, on the other hand, Mr. Darwin considered the Eocene sea of Chili to have been no warmer than at present, and $\mathrm{Mr}$. Tenison-Woods says that "the whole evidence of the [Tertiary] fossil corals shows a climate and isolation in the New-Zealand fauna not very different from the conditions which exist now," and that the Tertiary fauna of New Zealand generally " is not that of a warm sea, nor like what we should find on the warmer extra-tropical portions of the Australian coast" $t$. The Miocene Mollusca appear to me to indicate a rather warmer sea; but, as several of the species still live as far south as Foveaux Straits $\ddagger$ no elevation of temperature sufficient to take tropical and subtropical plants and animals to $50^{\circ} \mathrm{S}$. is probable; and, in addition to other dificulties presently to be mentioned, I shall, I think, be able to show that the South-American connexion is of a far older date than the Miocene. Before doing so, however, it will be necessary to give a short review of the fauna of the Australian region.

In Mr. Wallace's opinion the deep oceans, i. e. the Pacific, Atlantic, and Indian Oceans, have been in existence from the earliest geological times. All the principal groups of land animals, he thinks, have originated in the northern hemisphere, and have gradually migrated southwards through the continental extensions of America, Africa, and Australia (including the Indian archipelago), comparatively few having subsequently spread east and west by means of antarctic islands now submerged. If this be true, it is evident that the fauna of Australia ought to be more nearly allied to that of South Africa than to that of South America, because the connexion with the former by way of India is so much closer than the connexion with the latter by Kamschatka and Alaska. Let us see if this is so.

The Australian Mammalia are very peculiar, and are more closely allied to the Jurassic mammals of Europe and America than to any now living. The marsupials of America are related to the Eocene marsupials of Europe, and are evidently

- Quart. Journ. Geol. Soc. 1876, p. 345̃.

+ 'Palæontology of New Zealand, part iv. p. 4 (1880).

$\uparrow$ Such as Iolata pacifica, Triton Spzenglevi, Parmophorus unguis, Chione Stutchburyi, Tapes intermedia, Pertunculus laticostatus, Waldheimia lenticularis, and others. 
a younger branch of the family from which the Australian mammals had been separated long previously. Consequently the relationship between the American and Australian marsupials does not militate against Mr. Wallace's theory. The distribution of the birds is decidedly favourable to it. The flycatchers, sun-birds, hornbills, bee-eaters, king-crows, kingfishers, nightjars, swifts, bustards, and other Australian birds are all related to Old-World forms, exceptions perhaps being found in the Megapodes, or mound-builders, which are probably allied to the curassows of Brazil, and also in the brush-tongued parrots, which have their nearest allies in the parrots of South America.

Most of the families of lizards follow the same rule of distribution as the birds; but the Gymnophthalmidæ are not known in North America, although found in Timor, New Guinea, Polynesia, and South America ; and of the Iguanidæ (a characteristic South-American family) a very distinct species is found in Fiji, and another is supposed to occur in Australia. With the snakes the case is different. Out of the fourteen families of land-snakes inhabiting the Australian region, no less than four are found in India, A frica, and South America, but not in North America; and another family, the Amblycephalidæ, is found in India, in South America, and doubtfully in New Caledonia, but not in North America, although all, according to Mr. Wallace, must have passed through North America. The freshwater tortoises are found only in Africa, Australia, and South America. The principal genus, however, occurs both in Australia and in South America, but not in Africa. Here, therefore, the distribution is not in accordance with theory.

The affinity between the faunas of Australia and South America is still better shown in the frogs, whose distribution is quite at variance with that of the birds. One family (Pelodryadæ) is confined to these two regions; two others have the same distribution as the families of snakes just mentioned, being absent from North America, while closely allied forms are found in Australia and South America; and a family of tree-frogs, although widely spread and occurring in North America, has the South-American species more closely related to those of Australia than to those of North America.

The marine and most of the freshwater fishes (except Osteoglossum, which is found only in Borneo, Queensland, and Brazil), as well as some groups of insects, such as most of the buttertlies and stag-beetles, follow the same rule in distribution as the birds; while other groups of insects, such as the Buprestidæ, Longicorn beetles, and the family of Castniidæ among moths, follow the distribution of the frogs. 
The distribution of the marine Mollusca of Australia and Polynesia is favourable to Mr. Wallace's theory; but the terrestrial Mollusca, although most nearly allied to those of the Indian archipelago, have strong affinities with the Mollusca of South America, and show no connexion with those of Africa. 'This is seen in Trochomorpha, Tornatellina, Cyclotus, Cyclophorus, and Helicina, which are found in Polynesia, Australia, and South America; Macrocyclis, in Australia and South America ; Partula (a characteristic Polynesian genus) is found also in South America; Placostylus is allied to Orthalicus of Chili, Peru, and the Solomon Islands; and Vaginulus, a marine pulmonate, occurs in India, the Philippines, and in South America. This remarkable distribution is very instractive; for as the marine shells of the Indo-Pacific province have been unable during the whole of the Tertiary era to cross from Polynesia to America, it follows that when the ancestors of these land-shells crossed, the physical geography of the region must have been very different from what it is now, for there is no trace of their having passed into South America from the north.

We see, then, that the Australian fauna consists of three elements. The first is typified by the mammals, and is characteristically Australian. The second is typified by the birds, and is more nearly related to African than to American forms. The third is typified by the frogs, and is more nearly related to South America than to any other part of the globe. There is also a fourth element-the antarctic-which $I$ pass over for the present.

Now it is very difficult, or even impossible, to believe that all the groups of semitropical plants and animals which connect Australia, Polynesia, and even the Sandwich Islands with South America have travelled down from the north by the present land-routes, for then we should have to suppose that all had become extinct in North America, and certainly we should expect to find the connexion between Australia and Africa at least as close as it is between Australia and South America, which is not the case. But even if we got over this difficulty, we should still be unable to explain the facts. If, for example, the frogs had passed into South America by the same route as the birds, both would have shown a similarity in their distribution. The assumption that the present frogis are mere relics of a formerly more extended distribution, and that allied groups have become discontinuous through extermination, will not help us; for if all birds were now to become extinct north of the equator, we should still find the avifauna of Australia more nearly related to that of Africa than to that of South America; and it is 
impossible, by assuming any reasonable amount of extermination, to make the distribution of birds accord with that of the frogs. The lines of migration of frogs must therefore have been different from those of birds. Again, Mr. Wallace himself allows that salt water is almost a complete barrier to the dispersal of frogs * ; consequently where frogs could pass birds could pass also; and as the former have passed between Australia and South America, but not the latter, it follows that the two could not have spread together, but each must have pursued a different route at a different time. And as the present shape of the land accounts for the distribution of the birds, the distribution of the frogs must have taken place before the present groups of birds were in existence. But birds of many kinds were abundant in Europe and in America in Eocene times; and as we know that penguins inhabited New Zealand at the same period, it is probable that birds then existed in Australia also. Consequently the South-American migration must have taken place before the Eocene, and cannot be referred to a warm Miocene period. Evidently, therefore, the existence of the SouthAmerican element in the Australian fauna and flora requires some explanation which Mr. Wallace's hypothesis does not supply.

It was these considerations, together with the fact that the earthquake-wave of 1868 had proved that the average depth of the South Pacific Ocean was not great, which led me in 1872 to propose the hypothesis that in the Lower Cretaceous period an antarctic continent extended northwards into Polynesia, connecting Australia with South America and, perhaps, with South Atrica. I introduced the African connexion solely to account for the distribution of the Struthious birds; but I am now satisfied that Mr. Wallace's explanation of the spread of these birds from the north is more correct; and no reason therefore remains for supposing that Australia was ever connected with A frica. But the evidence of a connexion with South America is stronger than ever. Nevertheless I now abandon the idea of an extensive antarctic continent, because the soundings that have been lately taken in the Pacific Ocean have shown that such a supposition is highly improbable. At the same time these soundings have made it clear how the connexion really took place.

The surveys of the 'Tuscarora,' the 'Gazelle,' and the 'Challenger' have proved that a vast submarine plateau, nowhere more than 2000 fathoms below the sea-level, runs

$$
\text { * 'Geographical Ijstribution of Animals, i. p. } \$ 16 \text {. }
$$


from New Guinea and North Australia in an easterly direction through the Fiji and Tonga Islands to Samoa, spreading south to New Zealand and north to the Ellice, Gilbert, Marshal, Caroline, and Pelew Islands. This plateau is split into two portions by a deep narrow channel, which runs between New Zealand and the Kermadec Islands and between New Caledonia and the New Hebrides until it almost reaches Torres Straits. Another submarine plateau, also never more than 2000 fathoms below the sea-level, extends from Chili in a north-west direction to the Society Islands and Cook's Islands, including Juan Fernandez, Laster Island, the Paumotus, and the Marquesas Islands. Between Cook's Islands and the Samoa Islands there is a deep channel, but whether this is continued into the deep sea north of Samoa or whether the two plateaux are continuous is uncertain. Mr. Wild, of the 'Challenger' Expedition, says, "It seems as if an almost uninterrupted area of elevation crossed the whole basin of the Pacific in a north-westerly direction from Patagonia to Japan" *, probably about 1500 fathoms from the surface. North of this plateau the ocean averages 3000 fathoms in depth. To the south it ranges from 2900 to 2600 fathoms, getting gradually shallower towards the south-east. The shallowest part of the plateau is the ridge, already mentioned, between New Zealand and North Australia, which is nowhere more than 1000 fathoms below the surface.

Here we have probably the remains of an ancient continental area, which bridged the South Pacific and allowed the passage of frogs, land-shells, insects, and plants between New Guinea and South America, but which became submerged before the present groups of birds had come into existence. The date of this South-Pacific continent must have been anterior to the marine Indo-Pacific fauna, because hardly any of the fishes, Crustacea, and shells of Polynesia have crossed over to America; and it must have been posterior to the appearance of dicotyledonous plants. Now of the genera of marine shells characteristic of the Indo-Pacific fauna and not found on the American coast, Turbinella, Ricinula, Tridacna, and Aspergillum are Miocene; Rimella, Rostellaria, Seraphs, Dolium, Ancillaria, Cardilia, Pythina, and Glaucomye are Eocene; while Vulsella is found in the Upper Cretaceous rocks. A few others, such as Nautilus, Stomatia, and Neritopsis, are old forms apparently dying out. 'The genus Monoceros is also found in the Eocene rocks of Chili, but is not known in the Indo-Pacific province. We cannot therefore

$$
\text { * 'Thalassa, p. 22.2. }
$$


put the South-Pacific continent later than the Cretaceous period. On the other hand, though fossil plants belonging to the Jurassic period are known from many parts of the world, not a single Dicotyledon has as yet been found among them, the oldest known form being a poplar from the Lower Cretaceous beds of Greenland. In the Upper Cretaceous epoch dicotyledonous plants were abundant in Europe, North America, and in tropical Africa, and each of the three classes Monochlamydeæ, Polypetalæ, and Gamopetalæ were represented. The South-Pacific continent must therefore have existed after the Jurassic, and must have been submerged before the Eocene period.

Let us now see what light the geology of the surrounding countries throws on the subject. To commence with Chili: from Mr. Darwin's 'Observations on the Geology of South America' we learn that the fundamental rock-system of Chili and Western 'Tierra del Fuego consists of an irregular plateau of mica-schist and gneiss. On this floor immense masses of volcanic rocks, chiefly andesites and diorites, have been poured out from submarine volcanoes, forming the ranges of mountains called the Andes. 'These mountains are highest in the north, and get lower and lower southwards; but portions of volcanic rocks are found all through to Tierra del Fuego. High up among the volcanic rocks of the Andes in Chili a sedimentary gypseous system occurs, containing fossils of the Lower Cretaceous or perhaps Upper Jurassic period. Fossils of the same age are also found in a clay-slate system forming the eastern side of Tierra del Fuego and stretching far up the eastern flanks of the Andes. These Lower Cretaceous rocks go to a height of 14,000 or 15,000 feet above the sea. On the Atlantic side enormous plains of gravel and silt slope from the sea to an elevation of 8000 feet or more at the base of the mountains. On the Pacific side horizontal strata of probably Eocene age lie on the older rocks, and these are covered in places by gravel-beds, which go to a height of 1300 feet.

From these facts Mr. Darwin infers that during the Jurassic period this part of South America was a deep sea, on the bed of which volcanic eruptions took place. In the Lower Cretaceous it was shallow sea, with land in the neighbourhood, but the bottom was sinking, and it was further depressed for 7000 or 8000 feet, although the volcanic ejections continued to maintain land above the surface of the ocean. In the Upper Cretaceous period upheaval commenced, and, although interrupted by many oscillations, this upheaval has been going on ever since, until the elevation has been as much as 
14,000 or 15,000 feet, that is 2500 fathoms. Now it is fair to suppose that when the immense mass of Chili, part of Peru, La Plata, and Patagonia was depressed 2500 fathoms below its present level, a compensating elevation may have occurred in the South Pacific Ocean, and that as South America rose the bed of the Pacific sank. If this were the case, the SouthPacific continent must have been in existence in the Jurassic and Lower Cretaceous periods, and begun to subside in the Upper Cretaceous. The lowest portion, that between Samoa and the Society Islands, would have been submerged first, and the connexion between New Guinea and South America may have been severed before the close of the Cretaceous period. This conclusion agrees very well with that drawn, quite independently, from a study of the Australian fauna and flora.

On the western side of the South Pacific the oscillations of the land appear to have been much less. Of the geology of New Guinea it is known that Jurassic rocks are largely developed both in the north and in the south, which indicates that the land then stood at a lower level. No Cretaceous rocks are known from any part, and at this period therefore it may have been upheaved. Tertiary clays and limestones occur at Hall's Sound and at Yule Island; but as, according to Mr. Tenison-Woods, the fossils have nothing in common with those of Australia, their age remains at present doubtful *.

New Caledonia consists principally of two rock-systems, one of older Palæozoic, the other of older Mesozoic age. According to M. Garnier, Lower Cretaceous rocks are also found there; but the evidence appears to consist of a single fossil (Pinna) only.

In Eastern Australia and Tasmania the main range of mountains is formed of contorted schists and slates of Lower Palæozoic age. In New South Wales the denuded surface of these rocks is covered by enormous masses of shales and sandstones of Upper Palæozoic and Lower Mesozoic age, lying in a nearly horizontal position and forming the upper portions of the Blue Mountains. Further to the north, in Queensland, this system is overlain in places by rocks of Jurassic and Cretaceous age. Jurassic rocks are also found in Tasmania, Victoria, and in Western Australia; consequently we must suppose that during this period Australia was more depressed than at present, although not altogether submerged. During

* Mr. C.S. Wilkinson believes them to be of Lower Miocene age (Proc. Lim. Soc. N. S. Wales, rol. i. p. 114). For Mr. Tenison-Woods's opinion see the same publication, vol. vii. p. 382 . Formerly he considered them as probably older Pliocene (l. c. vol. ii. p. 127). 
the whole of the Cretaceous period all Central Australia and the whole of Queensiand appear to have been under the ocean, the Rev. J. Tenison-Woods having found Upper Cretaceous rocks on the very summit of the dividing range inland from Brisbane. But Western Australia, New South Wales, Eastern Victoria, and Tasmania remained above water. There are no Tertiary marine rocks on the east coast of Australia, and we must therefore assume that in the Eocene period Queensland was elevated, and from that time neither it nor New South Wales has ever stood much lower than at present. It also appears probable that the centre of the continent remained submerged until the close of the Miocene period or even later. But the geological evidence on this point is at present uncertain, for the "Desert Sandstone," so largely developed in the interior, and which lies unconformably on the Cretaceous system, is thought by Daintree and Clarke to be marine, by Etheridge to be lacustrine, and by TenisonWoods to be of æolian origin and of different ages. Marine Miocene rocks are found at an elevation of 800 feet above the sea * ; but as the central plateau of Australia rises to more than 1000 feet in the north, it would not necessarily be altogether submerged, especially as the northern parts of Australia appear to have been subsiding for a long time. On the other hand, Professor Duncan is of opinion that the Miocene sea of South Australia and Tasmania was of so high a temperature that it must have been open to the influx of warm currents from the north. Be this as it may, it is evident (1) that during the Jurassic and Cretaceous periods Australia stood at a lower level than at present, and (2) that it could not have been joined to New Guinea during the Cretaceous period, as supposed by Mr. Wallace, although this may very probably have occurred during the Eocene period.

Western Australia appears to have been more stable than any other part of the continent. The Darling range consists of granite, capped by sedimentary rocks of Upper Palæozoic age. On the east these ranges end abruptly in cliffs from 200 to 500 feet high, overlooking plains and salt-marshes composed of the "Desert Sandstone." Towards the sea, on the west, the granite disappears, and its place is taken by Upper Palæozoic rocks, which are overlain in places by another system of undoubtedly Jurassic age; and these are again overlain near the coast by wolian rocks of a recent date. Western Australia, therefore, appears to have been a

* C. S. Willinson, 'Notes on the Geology of New South Wales,' 1882, p. 57. 
land-surface during the whole of the Tertiary and Cretaceous periods, and perhaps it may date back to Triassic times.

The oscillations of land were on a much smaller scale in Australia than in South America, but they were somewhat similar. During the Jurassic and Lower Cretaceous periods both seem to have undergone subsidence; but while in South America elevation commenced in the Upper Cretaceous, in Australia it did not commence until the Eocene. This therefore agrees with, or at any rate in no way contradicts, the conclusion already arrived at, that the South-Pacific continent existed in the Jurassic and Cretaceous periods; but $\mathrm{New}$ Guinea, perhaps, was not connected until the Lower Cretaceous.

In the Pacific area itself all we know is that a sedimentary rock containing fossils occurs in the centre of Levuka, one of the Fiji Islands; and, according to Mr. Tenison-Woods, the fossils are of Tertiary, possibly early Tertiary, age, and show a tropical climate*. This is interesting to us as indicating that the South-Pacific continent was broken up in early Tertiary times.

Having thus got some idea of what has probably been going on in the South Pacific, we will now turn our attention to our own country, New Zealand. Sir Joseph Hooker, in the well-known introduction to his 'Flora Novæ Zealandiæ,' published in 1853, divides our flora into five elements :-(1) Australian, (2) S. American, (3) North Temperate, (4) Antarctic, and (5) Polynesian; and he thinks that a land communication, not necessarily continuous, is required to account for the presence of each of these elements, although the different communications may not have been at the same epoch. I do not mean on the present occasion to touch the North Temperate and Antarctic elements further than to show that, on the whole, they are of later origin than the other three, all of which, with few exceptions, are more or less subtropical in character. In my remarks I shall take all my data from Hooker's 'Handbook to the Flora of New Zealand' (1867), because, although many new species have been added since its publication, almost all are endemic and belong to genera already known from New Zealand; and as they are divided in nearly equal proportions between the Australian, SouthAmerican, and North Temperate elements, with a few Antarctic forms, their omission will not change in any appreciable degree the relative proportions of the flora of the 'Handbook.'

- Proc. Linn. Soc. of N. S. Wales, vol. iv. p. 358. 
Indeed, as Mr. G. M. Thomson has pointed out in his interesting address to the Otago Institute last year, "the general conclusions arrived at in the "Flora Novæ Zealandiæ' have not been materially altered by recent discoveries "*. For the local distribution of Australian plants, I have Baron von Müller's valuable 'Sỷstematic Census' (1882).

There are in New Zealand 35 subtropical or warmtemperate genera of flowering plants, which are also found in South America, and which probably did not pass from one country to the other by an Antarctic routet, and of these 31 occur also in Australia. These 35 genera contain 74 species, of which 89 per cent. are peculiar to New Zealand. If now we take the subtropical, or warm-temperate, genera, which do not occur in South America, we find that there are 33 of them $\ddagger$, of which 31 are also found in Australia. These genera contain 96 species, of which 93 per cent. are endemic. There are thus 68 genera which appear to have been introduced from the north, and to these we must add the greater part, at any rate, of the 41 genera which are confined to Australia and New Zealand, for 90 per cent. of the NewZealand species belonging to these genera are endemic. $\mathbf{M r}$. Wallace gives a list of 16 of these genera, which, not occurring in tropical Australia, he supposes must have migrated to or from New Zealand across the sea; and he says that nearly all these genera have in their seeds special facilities for transmission. But just as good reasons could be found for showing that many of his tropical genera have equal facilities for transmission; and as 87 per cent. of the New-Zealand species belonging to these 16 genera are endemic, while of the 33 genera named by Mr. Wallace as having come from the north, only 72 per cent. of the species are endemic, we must conclude that the 16 temperate genera have been in $\mathrm{New}$ Zealand as long as the 33 subtropical genera. As a matter of fact, 15 out of the 16 are found in Queensland; and it is

* Trans. N. Z. Institute, vol. xiv. p. 486.

† They are Drimys, Aristotelia, Discaria, Dodonaa, Sophora, Weinmannia, Gunnera, Eugenia, Fuchsia, Passiflora, Sicyos, Eryngium, Oreomyrrhis; Griselinia, Loranthus, Viscum, Lagenophora, Pratia, Myrsine, Sapota, Seboa, Calceolaria, Gratiola, Vitex, Pisonia, Cassytha, Atherosperma, Peperomia, Piper, Libocedrus, Podocarpus, Libertia, Astelia, Cordyline, and Cyperus. Grasses omitted.

\pm They are Pittosporum, Melicope, Leptospermum, Metrosideros, Meryta, Coprosma, Stylidium, Cyathodes, Parsonsia, Mitrasacme, Geniostoma, Mazus, Tetranthera, Knightia, Exocarpus, Santalum, Epioarpurus, Elatostemma, Asearina, Dammara, Dacrydium, Dendrobium, Bolbophyllum, Sarcochilus, Gastrodia, Corysanthes, Microtis, Iyperanthus, Thelymitra, Freycinetia, Dianella, Areca, and Gahnia. 
more reasonable to suppose that some of the tropical species have died out in Australia than that all the 16 genera have crossed the sea, an opinion not shared in by Sir J. Hooker, or by Mr. T. Kirk*.

Passing on now to the probably antarctic genera, that is southern genera which have spread east and west in southtemperate latitudes, we find that they number $20 \dagger$, containing 76 species, of which only 60 per cent. are endemic. Nineteen of the species are also found in Australia or Tasmania, and 11 or 12 in South America. There are also 56 genera of north-temperate plants, which probably spread with the antarctic forms, containing 199 species, of which 67 per cent. are peculiar to $\mathrm{New}$ Zealand. The remaining 87 genera I am unable to place. Most of them belong to two or more geographical elements, but others-such as Fagus - are doubtful.

Statistical results like these are always open to the objection that the data on which they rest are incomplete and more or less erroneous (for example, Coriaria and Gunnera may belong to the antarctic element, and Drosera to the SouthAmerican). They also assume that the rate of variation is equable, which of course cannot be strictly accurate. But this method of investigation has been used with great success in geology, and it can, I think, be trusted here for establishing the two following conclusions:-First, that the northern immigration, taken as a whole, was anterior to the southern immigration, also taken as a whole ; and second, that the immigration of the subtropical South-American genera belongs to the first period and not to the last. The first conclusion is similar to that of Mr. Wallace, but arrived at in a different way. The second is opposed to Mr. Wallace's idea that the South-American plants passed through New Zealand and antarctic lands during a warm Miocene period, which is also opposed by the fact that a number of Australian genera are found in South America but not in New Zealand. The fact that very few of our South-American genera are absent from Australia, while a large number of our Australian genera are absent from South America, makes it probable that there have been at least two migrations into New Zealand from the north, and that the South-American element belongs to the first of these only. This is borne out by the distribution of

* See Trans. N. Z. Institute, vol, xi. p. 546.

† I take the following as typical :-Colobanthus, Oxalis, Accena, Donatia, Tillea, Drosera, Apium, Nertera, Abrotanella, Cotula, Forstera, Pernettya, Ourisia, Drapetes, C'allixene, Rostkovia, Gaimardia, Carpha, Oreobolus, and Uncinia. 
some of the groups. The best example perhaps is the Orchids, of which 18 genera occur in New Zealand. Of these 2 are endemic, and the other 16 are all found in Australia. Two occur also in New Caledonia, three in Polynesia, four in the Indian archipelago, and three in India, while one consists of a single species widely spread over Asia and Australia. None of them are found in South America. The path of the Orchids into New Zealand, by the Indian archipelago and New Caledonia, is thus plainly mapped out, and as none have passed into South America the migration probably took place after the South-Pacific continent had disappeared. The number of New-Zealand species of this order is 38 , of which 32 (or 84 per cent.) are endemic, so that the immigration must have been an early one. Other examples are found in Pittosporea, Rutaceæ, and Santalaceæ. Examples of the earlier SouthAmerican migration are seen in the Monimiaceæ and Chloranthaceæ, while examples of the antarctic migration are the Caryophyllex, the Geraniacex, and the Rutaceæ. It may be objected that the percentage of endenic species is greater in the Australian than in the South-American element, and therefore that the first must be the older. But the objection is not fatal, because, in the first place, we must remember that the American genera would continue to live in Polynesia, and would migrate into New Zealand again with the Australian forms, thus making the percentage nearly the same in each case; and, in the second place, one or two genera may be included in the South-American element which are really antarctic, and this would at once bring down the percentage of endemic species. This is a mistake which could not be made with the Australian genera.

The Kermadec Islands occupy a very important position for furnishing evidence of migrations into New Zealand from the north, but unfortunately very little is known of their flora. What is known shows a remarkable affinity to the flora of New Zealand. Of the 21 species of flowering plants collected by Dr. Macgillivray, only three (14 per cent.) are endemic, 17 are found in New Zealand (one of which is supposed to have been introduced into both places), and the other (Metrosideros polymorpha) inhabits Polynesia and New Caledonia. From this we must infer that at a comparatively late period New Zealand extended further to the north-east than at present; for if it had not done so the Kermadec plants would have been far more differentiated from those of New Zealand than they are. At the same time, as but few subtropical species are common to New Zealand and Australia, this land could not have extended far to the north- 
west; but we may perhaps refer to this period the introduction of several of those tropical species, such as Avicennia officinalis and Sicyos angularis, which are also found in Australia.

It would thus appear that there have been three migrations of plants from the north into New Zealand: two of very ancient date; the third comparatively recent and comparatively unimportant. The supposition that New Zealand was at one time connected with a South-Pacific continent, from which plants spread into South America and into New Guinea, and that, at a subsequent period, Eastern Australia was attached to New Guinea, and received from thence fragments of this Polynesian flora, together with plants of the Indian archipelago, will explain, I think, why some Polynesian and South-American genera are found in New Zealand but not in Australia, and why some occur in Australia but not in New Zealand.

Passing on now to a consideration of our fauna, we find it composed of the same elements that we recognized in the flora, viz.-(1) Australian, (2) Polynesian, (3) S. American, (4) Antarctic, and (5) North 'Temperate. 'The South-American element seems to be the weakest, but until the distribution of our insects, land-mollusca, and land-worms is better known we cannot speak with any confidence on this point. ( ne of our two bats was formerly thought to belong to an American family; but this has been shown to be a mistake, and it now seems that both are of Old-World extraction. This removes a difficulty, for bats are certainly not a more ancient group than birds, and it would have been very puzzling if their distribution had coincided with that of the frogs instead of with that of the birds.

Our birds show only three elements:-(1) an Antarctic, which comprises the penguins, the petrels, three out of five gulls, and four out of nine cormorants; (2) a Polynesian, consisting of the paroquets, Aplonis, and the long-tailed cuckoo; and (3) an Australian, which includes all the rest, except a few which are cosmopolitan. Of a South-American element we see no trace except it be in Nestor, which may be distantly related to the macaws, although still more nearly to the brush-tongued parrots of Australia and Polynesia. The Merganser of the Auckland Islands may represent the NorthTemperate element. The affinities of Turnagra are still doubtful. I pointed out in $1872^{*}$ that our land-birds had been derived from the north, and Mr. Wallace has subse-

- Trans. N.Z. Institute, vol. v. pp. 251, 252.

Ann.\& Mag. N. Hist. Ser. 5. Vol. xiii. 
quently, but quite independently, arrived at the same conclusion. While, however, Mr. Wallace thinks that the birds migrated along a land-communication with Northern Australia in the Cretaceous period, I was, and still am, of opinion that the fragmentary nature of our avifauna shows that the land was not continuous, but was interrupted by an arm of the sea between New Caledonia and the mainland, and further, that this communication took place in the Eocene and not in the Cretaceous period. The remarkable fact that both our cuckoos migrate annually to New Zealand from Australia or Polynesia indicates, as I explained in my former paper, a much more recent northern extension of New Zealand, and this agrees with the evidence given by the flora of the Kermadec Islands. Mr. Wallace refuses to believe that these birds migrate, and thinks that they retire to some unexplored parts of the islands in the winter, but unfortunately he gives no hint as to where these unexplored parts are situated.

Our lizards show an Australian element in Mocoa and Itinutia; but the genus Naultinus is endemic and belongs to a group of geckos tound in Abyssinia, India, the Indian archipelago, Australia, and Chili. Syphenodon belongs to New Zealand only. Our single species of frog has decided SouthAmerican affinities.

Of the freshwater fishes Eleotris is an Indian-archipelago and Australian genus, but as it is also found in Mexico and the West Indies it may possibly indicate a South-American element; Galaxias, Cheimarrichthys (an endemic genus allied to Aphrites), Prototroctes, and the lampreys are Antarctic; while the eels are Australian or Polynesian. The marine fishes are a southward extension of the Indo-Pacific fauna, with a strong Antarctic element in Bovichthys, Notothenia, Thersites, Gonorhynchus, Callorhynchus, and perhaps in Genypterus and others.

The land molluscan fauna appears to consist of Australian, Polynesian, and South-American elements, the latter being marked by Tornatellina, Amphidoxa, Cyclotus, and perhaps Strobila. There is no Antarctic element. In my paper on the "Geographical Relations of the New-Zealand Fauna" I stated that the freshwater shells showed a Polynesian affinity distinct from the Australian; but in this I was mistaken, owing to my want of knowledge of the Australian fauna. It now appears that most of the genera are also Australian; but Melanopsis is Polynesian, and Potamopyrgus is said to occur in South America. 'The affinities of our freshwater limpet (Latia) are not known. The marine Mollusca are, like the 
marine fishes, a southward extension of the Indo-Pacific fauna with a well-marked Antarctic element, the South-American element being but slightly developed. The main point of interest is the difference exhibited between them and the marine Mollusca of temperate Australia and Tasmania, shown chiefly in the absence from our seas of many common subtropical forms. Tasmania, for example, possesses several species of Conus, Cyproea, Fasciolaria, and Oliva, of which we have no representatives. We have but one species each of the genera Nitra, Columbella, and Nassa; while Tasmania has respectively 14,10 , and $\bar{\partial}$ species. We have only 3 species of Voluta and 2 of Marginella, while Tasmania has 7 of the former and 8 of the latter. This great difference is probably accounted for by the warm south-east current that Hows down the coast of Australia, and the cold south-west current that sweeps the shores of New Zealand. If, however, New Zealand was joined to Northern Australia or New Guinea all this would be changed; the warm current would pass down its east coast, while the cold current would be deflected from the west coast of New Zealand to the east coast of Australia. But the difference in the shells was nearly as well marked in Tertiary times as now; consequently we must suppose that New Zealand has been isolated, and that the warm current has passed down the east coast of Australia ever since these genera inhabited the districts. Now Voluta, Mitra, Conus, Fasciolaria, and Cyproea date from the Upper Cretaceous, the others from the Eocene, and the conclusion seems plain that New Zealand has not been connected with Australia since the Cretaceous period, which agrees well with the inference derived from the fragmentary nature of our avifauna.

The geographical relations of our insects and spiders are not yet known, but as the families of insects in many cases date back to the Jurassic, and several genera to the Cretaceous period, we may expect to find a marked South-American element among them; indeed, Mr. Meyrick has, in papers read to our society, already pointed out that in the Crambidæ the New-Zealand species of Diptychophora are more closely related to South-American than to the single Australian species; and that among the Geometrina the genera Azelina, Drepanodes, and Siculoides are South American, while Tatosoma is found in Europe, Ceylon, Borneo, Australia, and South America, the New-Zealand species being nearest to those of South America. Peripatus is no doubt a very old form; it is found in South Africa, Chili, Central America, and the West Indies, and consequently cannot be considered 
as representing an Antarctic element, but must be referred to the South-American migration.

It is very remarkable that our crayfishes should belong to the same genus as the species found in Fiji, while those of Australia and South America are generically distinct, although all belonging to the same subfamily. This, I think, proves incontestably that Fiji and New Zealand have had direct land-communication; for Prof. Huxley has pointed out that fresh water crayfishes are very ill adapted for crossing even a narrow arm of the sea. Mr. Wallace thinks that this connexion with Fiji " is hardly probable, or we should find more community between the productions " of the two countries; but when we remember the difference of climate we cannot expect a greater community than actually exists. The marine Crustacea agree with the marine fishes and shells in having well marked Australian and Antarctic elements, but perhaps it is not yet possible to distinguish South-American from Antaretic forms. It will not be necessary to pass in review the lower classes of animals; but little is as yet known of them, and at present they throw no new light on the origin of our fauna.

I will now recapitulate the results we have arrived at about the New-Zealand flora and fauna. The South-American element in the fauna and flora, as shown by the plants, frog, land-mollusca, and insects, proves that New Zealand was closely connected with the South-Pacific continent which probably existed in Jurassic and Lower Cretaceous times, while the distribution of the freshwater crayfishes proves that Fiji and New Zealand have had a continuous land-communication. The distribution of the marine Mollusca shows that New Zealand has been separated from all northern lands ever since the Cretaceous period, and this explains the fragmentary nature of the avifauna. At the same time, the fact that many birds, land-shells, and plants, showing no South-American relations, have passed to New Zealand from the north-west, proves that these islands, although not actually connected, must have extended much further north and approached much more nearly to Queensland and New Guinea at some period in the Tertiary era than they do now, and that that period was an early one is shown by the amount of change that has since taken place in both plants and animals. The flora of the Kermadec Islands, and the remarkable phenomenon of our migratory cuckoos, give evidence of a third north-easterly extension of New Zealand at a much later date; but the absence of many common types of Australian birds, and the small number of northern plants and animals specifically 
identical with those of Australia, prove that this extension was much less than the other two, and perhaps did not last long. It is now necessary to examine the geology of New Zealand, and see how it bears on the subject.

New Zealand is a mountainous country, partly covered with forests, and difficult to explore geologically, and the fossils, although largely collected, have as yet been but little studied. It is not therefore surprising that many points in its geology remain uncertain, especially as to the ages to be assigned to the several rock-systems of which it is composed, and which, being commonly discontinuous, require the aid of palæontology for their elucidation more than in most countries. Nevertheless, thanks to the energy and skill with which the Geological Survey department has during the last twenty-two years attacked the problem, I think I am safe in saying that the main structure of the country is tolerably well known, especially in those points which alone concern us here, and which I will briefly mention.

The main range forming the New-Zealand Alps in the South Island, and the mountains stretching from Wellington towards the East Cape in the North Island, is composed of highly-inclined sedimentary rocks belonging to four, or perhaps five, distinct systems. The first is probably Archæan or Cambrian. According to Dr. Hector the second is Ordovician, the third Silurian and Lower Devonian, the fourth Upper Devonian and Lower Carboniferous, while the tifth ranges from Permian to Jurassic. This last system contains fossils related to those from the Gondwana system of India and the newer Carbonaceous system of Eastern Australia. According to Mr. S. H. Cox, it is about 21,000 feet in thickness, and is entirely a littoral formation, plant-remains being found all through it; thus implying a subsidence of 3500 fathoms in early Mesozoic times. The axis of the geanticlinal, however, is not in the centre of the range, but lies along its western base, the whole western portion of the elevated mass having been removed by denudation, except in the west part of Nelson and the north part of Auckland. Of the rest, all that remains is the submarine platean which stretches out towards Australia.

The next system of rocks is of Cretaceous, probably Upper Cretaceous, age*. Along the eastern base of the main range it lies quite unconformably on the Jurassic and older rocks, and, according to Dr. Hector and Dr. von Haast, it is also

- Dr. Hector considers the oldest beds to be the equivalent of the Lower Greensand of England. 
found in a similar position on the west coast of the South Island: thus lying at a low level on the geanticlinal axis. In the North Island the geanticlinal axis is covered by thick masses of Tertiary sedimentary and volcanic rocks, which hide the Cretaceous system if it exists there. Evidently a great upheaval, followed by enormous denudation, must have taken place immediately before the deposition of this last rock-system, that is at the close of the Jurassic and commencement of the Cretaceous periods. There may be some doubt as to the exact time of this upheaval, but that the NewZealand Alps were principally formed during the periods mentioned is unquestionable.

The Cretaceous, or according to Dr. Hector the CretaceoTertiary, system has also been much disturbed in places, and is everywhere denuded, and generally overlain unconformably by beds of Oligocene and Miocene age. This proves that a second elevation, probably of less extent than the first, took place in the Eocene period, and was followed by a second depression in the Oligocene. The Oligocene and Miocene marine rocks are largely developed, and extend to a height of 2500 feet above the sea , proving conclusively that during this period New Zealand was represented by a cluster of twenty or more islands, on which, as I pointed out in 1872 , the various species of moa were probably developedt. Since that time a third elevation has taken place, the proofs of which I must defer to another opportunity. 'These three elevations agree quite with the conclusions already arrived at by a study of the fauna and flora; and we must suppose that it was during the Upper Jurassic or Lower Cretaceous period that New Zealand was joined to the South-Pacific continent, while during part of the Eocene it extended towards New Caledonia, and again in the Pliocene towards the Kermadec Islands.

Our general results, then, are that in early Mesozoic times New Zealand, Eastern Australia, and India formed one biological region, land probably extending continuously from New Zealand to New South Wales and Tasmania. At the close of the Jurassic period the New-Zealand Alps were upheaved, and the geosynclinal trough between New Zealand and Aus-

* A ccording to Dr. von Haast they ascend to 5000 feet above the sea, but no localities are given ('Geol. of Canterbury and Westland,' 1879, p. 305$)$.

+ Mr. Wallace agrees with this opinion, but in his 'Island Life' says that it is a pure bypothesis, of which we have no independent proof; he not, as I suppose, being aware of the distribution of our Nilocene rocks, although I mentioned it in my paper (see Trans. N.Z. Inst. vol. v. p. 253). 
tralia was formed. During the Lower Cretaceous period a large Pacific continent extended from New Guinea to Chili, sending south from the neighbourhood of Fiji a peninsula that included New Zealand. Nearly all the southern part of America was submerged. Western Australia and Eastern Australia formed two large islands lying at some distance from the continent. This continent supported dicotyledonous and other plants, insects, land shells, frogs, a few lizards, and perhaps snakes and a few birds, but no mammals. In the Upper Cretaceous period New Zealand became separated and reduced to two small islands; the South-Pacific continent divided in the middle between Samoa and the Society Islands, and (the eastern portion being elevated while the centre sank) it ultimately became what we know now as Chili, La Plata, and Patagonia. In the Eocene period elevation commenced in our district; Eastern Australia was joined to New Guinea, which stretched through New Britain to the Solomon Islands. New Zealand was also upheaved and extended towards New Caledonia, but the two lands were divided by an arm of the sea. The mainland of New Guinea had by this time been invaded from the north by a large number of plants, birds, lizards, snakes, \&c., which migrated south into Eastern Australia, and a few passed over the New-Caledonia channel and reached New Zealand. But still no mammals. In the Oligocene period New Zealand again gradually sank, carrying with it the sparse flora and fauna it had received, and in Miocene times was reduced to a cluster of islands, Eastern Australia all this time receiving constant additions to its fauna and flora through New Guinea. In the Pliocene period elevation once more took place; New Zealand extended towards the Kermadec Islands, and the continent of Australia was formed; after which subsidence again occurred in the New-Zealand area.

These conclusions are more precise, but are much the same as those at which $I$ arrived in 1872, with the exception that I now substitute a South-Pacific continent from which Australia was isolated, for the Lower Cretaceous Antarctic continent of my former paper. Mr. Wallace's hypothesis of an isolated West-Australian continent on which the characteristic Australian flora and mammalian fauna were developed is fairly satisfactory, but I presume that the Australian birds are not supposed to belong to the West-Australian fauna. A few, such as the ancestors of the honey-suckers and the brushtongued parrots, may have crossed over the sea from New Guinea to Western Australia, but the mass of the birds are supposed to be East-Australian, to have passed into West 
Australia by the north while the continent was being upheaved and its climate still humid, and to have become differentiated since the entire drying up of the interior sea so desiccated the country as once more to isolate West. Australia almost as effectually as if it were surrounded by water. But $\mathrm{Mr}$. Wallace does not make this sufficiently clear. When, however, we come to that part of Mr. Wallace's hypothesis which deals with the connexion between Australia and New Zealand we find it to be not so satisfactory. In the first place, the facts of geology are against any connexion having taken place between the two countries at the time supposed. In the second place, the South-American element in the fauna and flora is not separated from the Antarctic element. In the third place, the hypothesis fails to explain the South-American element, except on the supposition of large extensions of land during the warm Miocene period, for which there is no sufficient evidence, and which if it had occurred would have allowed birds as well as frogs and land-shells to pass. And in the fourth place, it ignores altogether the special relation which exists between New Zealand and some of the islands in the Pacific. The hypothesis here proposed is no doubt incomplete, and will be much improved when the palæontology of New Zealand is better known; but it does, I think, give a fairly satisfactory account of the origin of the SouthAmerican, Australian, and Polynesian elements in our fauna and flora. The Antarctic and North-T'emperate elements still remain for consideration; but so wide a subject cannot be entered upon at the end of an address, and I must postpone all discussions to some future occasion.

\section{XLIX.-Description of a new Genus of Fossit Fishes from the Lias. By Janes W. Davis, F.G.S. \&c.}

[Plate XVI.]

\section{Genus Lissoleris, Davis.}

Class Pisces. Subclass Pal zitchthxes. Order Ganoider.

Suborder AcIPfnseroidei. Family Palazoniscidas.

Body fusiform; head large; gape wide; jaws elongated, furnished with closely-set uniform enamel-tipped teeth; scales of medium size, rhomboidal, mostly with smooth surface, a few anterior ones with slight furrows, posterior margin serrated; 